\title{
Heartworm disease (Dirofilaria immitis) and their vectors in Europe - new distribution trends
}

\author{
Rodrigo Morchón ${ }^{1}$, E. Carretón ${ }^{2}$, J. González-Miguel ${ }^{1}$ and I. Mellado-Hernández' \\ ${ }^{1}$ Group of Dirofilariosis, Faculty of Pharmacy, Institute of Biomedical Research of Salamanca, University of Salamanca, Salamanca, Spain \\ 2 Internal Medicine, Faculty of Veterinary Medicine, University of Las Palmas de Gran Canaria, Las Palmas, Spain
}

Edited by:

Rubén Bueno-Marí, University of

Valencia, Spain

Reviewed by:

Giulio Grandi, Università degli Studi di Parma, Italy

Valladares Hernández, University of

La Laguna, Spain

Dario Vezzani, Consejo Nacional de

Investigaciones Científicas y Técnicas,

Argentina

*Correspondence:

Rodrigo Morchón, Faculty of

Pharmacy, University of Salamanca,

c/Licenciado Méndez Nieto $s / n$,

37007 Salamanca, Spain

e-mail:rmorgar@usal.es
Cardiopulmonary dirofilariasis is a cosmopolitan disease caused by Dirofilaria immitis, which affects mainly canids and felids. Moreover, it causes zoonotic infections, producing pulmonary dirofilariasis in humans. Heartworm disease is a vector-borne transmitted disease, thus transmission depends on the presence of competent mosquito species, which is directly related to favorable climate conditions for its development and survival. Cardiopulmonary dirofilariasis is mainly located in countries with temperate and tropical climates. Europe is one of the continents where animal dirofilariasis has been studied more extensively. In this article we review the current prevalence of canine and feline cardiopulmonary dirofilariasis in the European continent, the transmission vectors, the current changes in the distribution and the possible causes, though the analysis of the epidemiological studies carried out until 2001 and between 2002 and 2011. The highest prevalences have been observed in the southern European countries, which are considered historically endemic/hyperendemic countries. Studies carried out in the last 10 years suggest an expansion of cardiopulmonary dirofilariasis in dogs toward central and northern Europe. Several factors can exert an influence on the spreading of the disease, such as movement of infected animals, the introduction of new species of mosquitoes able to act as vectors, the climate change caused by the global warming, and development of human activity in new areas. Veterinary controls to prevent the spreading of this disease, programs of control of vectors, and adequate protocols of prevention of dirofilariasis in the susceptible species should be carried out.

Keywords: heartworm disease, Dirofilaria immitis, dogs, cats, prevalence, vectors, Europe

\section{INTRODUCTION}

Dirofilaria immitis is a parasitic nematode responsible of canine and feline cardiopulmonary dirofilariasis in both domestic and wild hosts, and the causal agent of human pulmonary dirofilariasis. It is a zoonotic parasitic disease mainly located in temperate, tropical, and subtropical areas of the world (Simón et al., 2009b). Different species of culicid mosquitoes (Culex spp., Aedes spp., Anopheles spp.) act as an intermediate stage in order to complete their life cycle. When taking a blood meal from a microfilaremic host, the mosquitoes become infected and the microfilariae develop to the third-stage larvae (L3) in the malpighian tubules of the mosquitoes (Cancrini and Kramer, 2001), which are deposited on the host while the mosquito is taking a blood meal, becoming sexually mature within a few months in the main pulmonary arteries and right ventricle.

Heartworm infection is a severe and life-threatening disease. Initially the pulmonary vasculature is affected, and the lung itself and, finally, the right chambers of the heart (Furlanello et al., 1998). Feline infection is diagnosed with increasing frequency in areas where the disease is endemic in canines. However, the development of the parasite in cats takes longer compared to dogs and most infections are amicrofilaraemic. Additionally, many cats tolerate the infection without any noticeable clinical signs or with signs manifested only transiently and sometimes sudden death may arise without warning (Genchi et al., 1992; McCall et al., 2008).

The presence of $D$. immitis in dogs constitutes a risk for the human population. In the human host is the causative agent of the pulmonary dirofilariasis and in many cases produces benign pulmonary nodules which can initially be misidentified as malignant tumors (Simón et al., 2005).

The transmission of infectious diseases is influenced by many factors, including climatic and ecological elements. It is widely anticipated that climate change will impact the spread of vectorborne diseases in Europe, since arthropod vectors are especially sensitive to climatic factors. Weather influences the development and maintenance of the vectors, but climate change is one of many factors that influence vector habitat. Several studies have described the effects of the climate change in the spreading of other vectorborne diseases in Europe (Semenza and Menne, 2009; Genchi et al., 2011a,b).

The aim of the present work is to review the current epidemiological situation of the cardiopulmonary dirofilariasis in dogs (the main host) and cats in Europe, its vectors and evaluate the possible causes of the changes in the distribution of the disease by conducting a retrospective analysis of the epidemiological situation. 


\section{EPIDEMIOLOGICAL DISTRIBUTION OF ANIMAL DIROFILARIASIS IN EUROPE UNTIL 2001}

Until 2001, cardiopulmonary dirofilariasis was mainly found in the southern European countries, such as Spain, Portugal, Italy, and France. Greece, Turkey, and some Eastern countries reported a few scattered studies while in central and northern European countries only isolated cases were reported (Figure 1).

In Italy, the area of highest prevalence values for dogs and cats was along the Po River Valley in northern Italy, where the prevalence rate for dogs ranged from 50 to $80 \%$ in animals no treated with preventive drugs (Genchi et al., 2001). A study of 1986 defined as infected by $D$. immitis $50 \%$ of the Northern provinces and only $15 \%$ of the provinces of central and southern Italy (Pampiglione et al., 1986). In the 1980s and 1990s, D. immitis showed a relevant prevalence increase in endemic areas (Genchi et al., 2001) and it was also recorded outside the main endemic area of the Po Valley, in provinces of north-eastern Italy previously regarded as non-endemic (Poglayen et al., 1996). Similarly, in Piedmont, an extensive survey carried out in the 1990s reported a spread of $D$. immitis westward and south-westward of the traditional endemic area, where $D$. immitis infection successfully established in hilly and pre-alpine areas as well in urban areas (Rossi et al., 1996). The disease was also present northwards into the provinces of FriuliVenezia-Giulia (Pietrobelli et al., 1998). Heartworm disease has also been reported in central areas of the country, which showed lower infection rates for D. immitis, i.e., Toscana and Umbría (Magi et al., 1989; Pietrobelli et al., 1998; Genchi et al., 2001), except the Tuscan coast, where Magi et al. reported prevalences higher than $28 \%$ in 1989. Epidemiological data on the occurrence of dirofilariasis by $D$. immitis in southern Italy are scant (Cringoli et al., 2001) and limited to sporadic case reports, though no infection or very low prevalence were found in these areas, where $D$. immitis prevalence (microfilaremic dogs) was $0.01 \%$ in Sicily (Giannetto et al., 1997) and 0.5\% in Campania (Cringoli et al., 2001). In Sardinia a prevalence of $4.1 \%$ in the southern area of the island was reported (Arru et al., 1968). The infection by D. immitis in cats is documented in northern Italy, where the prevalence rate in the hyperendemic areas resulted to be up to $24 \%$ (Genchi et al., 1992, 1993, 2001), while the presence of heartworm in feline populations of other areas of Italy was not investigated so far. Cases of foxes infected by $D$. immitis in Tuscany were described (Gradoni et al., 1980; Marconcini et al., 1996).

In Spain, D. immitis was found in large areas of the country, although the prevalence of the disease was higher in the southern areas, where the reported prevalence was $8.5 \%$ in Andalucia, $6.7 \%$ in Extremadura, or 6.3\% in Murcia; indeed, in the Iberian peninsula, the highest prevalence was $36.7 \%$ in the southern province of Huelva (Guerrero et al., 1989; Ortega-Mora et al., 1991). Other southern areas with high prevalences were found in Cadiz (12\%), Córdoba (18\%), Badajoz (8-14\%), or Alicante (13\%; Anguiano et al., 1985; Guerrero et al., 1989; MSD-AGVET, 1991; OrtegaMora et al., 1991). In the rest of the Iberian Peninsula, the higher prevalences were associated with irrigated areas. In the central areas of Iberian Peninsula low prevalences of canine dirofilariasis were reported. In Madrid, several studies stood the canine prevalence between 1.1 and 2\% (Ortega-Mora et al., 1988; Guerrero et al., 1989; Rojo-Vázquez et al., 1990), except in the area of Aranjuez (population under the influence of the river Tajo), where Guerrero et al. (1992) reported a prevalence of 6.8\%. In the northwest of Spain, the prevalence reported in Salamanca was $12 \%$, rising to $33.3 \%$ in irrigated areas close to the river Tormes (Pérez et al., 1989). In the northeast of Spain, the highest prevalences were found in Zaragoza (13.5\%; Castillo et al., 1989), where high prevalences in irrigated areas were found in foxes (31.5\%; Castillo et al., 1989). In Catalonia the global prevalence remained low $(2.17 \%$ region of Catalonia; 1.2\% district of Barcelona; Rojo-Vázquez et al., 1990; Gutiérrez et al., 1995); Guerrero et al. (1995) reported an increase of the prevalence of $D$. immitis infection in dogs in Catalonia from $0.38 \%$ in 1989 to just over 5\% in 1995. Besides, the prevalences in this area raised noticeably in the irrigated areas,

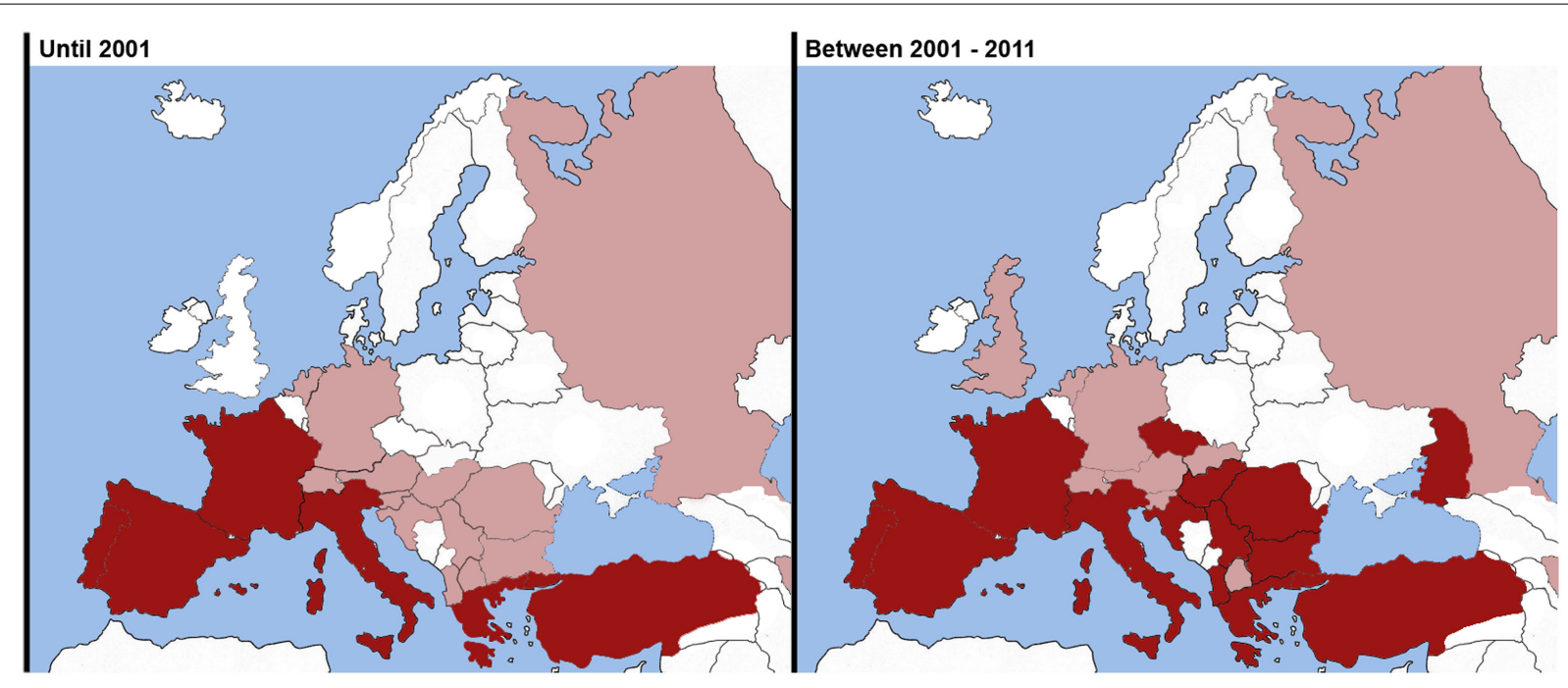

FIGURE 1 | Comparison of geographical distribution in Europe of heartworm disease observed in dogs between 2001 and 2011. Endemic areas (Red). Sporadic cases reported (Pink). *Ilustrated map taking into account Genchi et al. $(2005,2009)$ and data from the referenced literature. 
such as River Ebro Delta (35.8\%; Anguera-Galiana, 1995) and Bajo Llobregat (12.8\%; Aranda et al., 1998). Canary Islands, sited in front of the north-western African coast, were considered an endemic area of the disease. On the island of Gran Canaria, serial epidemiological studies carried out in different years allowed monitoring the evolution of the canine dirofilariasis. These studies showed an increase in the prevalence from $36.7 \%$ in 1989 to $58.89 \%$ in 1998 , reaching the highest prevalence (67.02\%) in 1994. This is the highest prevalence reported in Spain so far (Montoya et al., 1998). The island of Tenerife, on the other hand, showed a drop of prevalence from $41.8 \%$ in 1984 to $23 \%$ in 1999 (Valladares et al., 1987; Guerrero et al., 1989; Stenzenberger and Gothe, 1999). Infections by $D$. immitis in foxes, were reported with the highest prevalence found in foxes from irrigated areas $(32 \%)$, while in semiarid regions the prevalence was much lower $(1.7 \%)$ and in mountain foxes heartworm was absent (Gortázar et al., 1994, 1998). Finally, in the northern areas of the Iberian Peninsula no cases of canine dirofilariasis were reported (Guerrero et al., 1989, 1992) although exist a report of $D$. immitis infection in a wolf (Segovia et al., 2001).

In Portugal, the only study published showed that canine heartworm infection was prevalent in several southern regions of Portugal, including Ribatejo (16.7\%), Alentejo (16.5\%), and Algarve (12\%). The Island of Madeira had the highest prevalence with 30\% of the dogs tested being positive for D. immitis microfilaremia (Araujo, 1996).

In France, D. immitis occurred mainly in the South, along the Mediterranean coast, predominantly in Bouches du Rhône, Vancluse, and Corse Island (5-15\%), and to a lesser extent, in Haute-Garonne and Dordogne (Doby et al., 1986a; Guerrero et al., 1992). The overall prevalences of canine dirofilariasis reported in France were $0.74 \%$ in $1986,1.48 \%$ in 1988 , and $0.8 \%$ in 1989 (Ducos de Lahitte, 1990; Guerrero et al., 1992). D. immitis infections were reported beyond the Mediterranean, in field studies with positive findings in Normandy and Brittany in the Northwest of France, as well as in the department of Dordogne in the southwest. Doby et al. reported in 1986 canine prevalences in Brittany of between 3.7-10\%, and 5\% in Normandy (Doby et al., 1986b; Ducos de Lahitte, 1990). Guerrero et al. (1992) reported in 1992 prevalences in $7.3 \%$ of the dogs tested in Alpes Maritimes and $2.5 \%$ in dogs examined in Pyrenees Atlantique; nevertheless, most of these dogs had lived in french-administered territories outside of the European continent. The parasite was also diagnosed in northern France (Cherburg area, just below $50^{\circ} \mathrm{N}$ latitude), showing a prevalence of $3.7 \%$, apparently as consequence of autochthonous infection (Doby et al., 1986a). In cats, microfilariae of $D$. immitis were detected in the urine, but not in the blood, of a cat in Sommieres, in southern France. The cat also showed radiographic evidence of $D$. immitis infection (Beaufils et al., 1991).

In Greece a study carried out between 1987 and 1991 showed microfilariae of D. immitis in the $10 \%$ of the studied dogs (Papazahariadou et al., 1994) while in 1999 in dogs from the area of Macedonia the reported prevalence was $34.13 \%$ (Founta et al., 1999). In general, in Greece during the 90s decade the incidence of the disease increased rapidly and at the end of the millenium was considered endemic in the central and northern parts of the country (Polizopoulou et al., 2000). In a study carried out in 2001 in the Attiki region (south of Greece) low canine D. immitis prevalence $(0.7 \%)$ was observed (Diaku, 2001).

In Turkey, the first case of dirofilariasis reported in a dog date from 1951 (Güralp, 1981). Until 2001 only a few studies regarding the distribution and prevalence of animal dirofilariasis are published. In the Army Veterinary Research and Training at Gemlik, Bursa, 2.98\% of dogs were infected (Coskun et al., 1992), and in Ankara, between 2000 and 2001 a prevalence of $9.3 \%$ was reported (Öge et al., 2003).

In Switzerland, border country with Italy and France, Arnold et al. (1994) reported a case of an infected dog and suggested a possible autochthonous infection, which confirmed in 1998 (Genchi et al., 1998), moment at which Switzerland became an endemic country. In the south of Switzerland, between 1995 and 1998, the reported prevalences ranged from 0.6 to $1.07 \%$ (Deplazes et al., 1995; Bucklar et al., 1998). Deplazes et al. (1995) diagnosed another autochthonous case in a dog from the south of the country (Cantón de Ticino) close to Como and Varese (northern Italy). In the same region, in 2001 the prevalence raised considerably, reporting $10.7 \%$ of microfilaremic dogs and $3.2 \%$ of amicrofilaremic dogs, some of them also infected by D. repens (6\%; Petruschke et al., 2001).

In Germany, between 1993 and 1996 a total of 80 dogs were diagnosed, of which 45 were amicrofilaremic (Zahller et al., 1997).

In the Netherlands, seven cases of infected dogs were recollected between 1992 and 1993, the same amount of cases of canine dirofilariasis reported in the previous years (Meyer et al., 1994).

In the only study published in Macedonia, the prevalence reported was 0.9\% (Ježic and Simic, 1929).

In Rumania, at least four dogs were diagnosed between 1903 and 1935 (Genchi et al., 2001). Later, the average prevalence was $35 \%$ rising to $67 \%$ in some areas (Olteanu, 1996).

In the former Yugoslavia, in Croatia between 1987 and 1989 several cases of canine dirofilariasis were reported but no considered autochthonous (Brglez and Senk, 1987; Genchi et al., 2001). In Serbia the first report data from 1999 by Dimitrijevic (1999). In Slovenia and Bulgaria, the reported prevalence of D. immitis was around $4-5 \%$ (Olteanu, 1996), being in Bulgaria 1.4\% in pet dogs and $12.5 \%$ in stray dogs (Georgieva et al., 2001). In Albania, a study carried out between 1995 and 1996 with samples from the coastal western area showed infection in $13.5 \%$ of the dogs (Rapti and Rehbein, 2010).

In the former USSR (Russia) there are only 3-4 reports of isolated incidents of infection in dogs from the Republics of Azerbaijan and Turkmenistan, situated in the center of the country, in Ussuri Region in the Far East and in Abkhazia (Artamonova et al., 1997).

Finally, Switzerland, Netherlands, Germany, Austria, United Kingdom, and Hungary also reported dirofilariasis in imported dogs, or dogs previously living in endemic areas of Europe, the south of United States of America and/or Middle or Far East, fact that could distort the real prevalences of these countries (Stokhof and Wolvekamp, 1978; Boros et al., 1982; Hinaidy et al., 1987; Arnold et al., 1994; Meyer et al., 1994; Deplazes et al., 1995; Wohlsein et al., 1996; Zahller et al., 1997). 


\section{EPIDEMIOLOGICAL SITUATION OF ANIMAL DIROFILARIASIS IN EUROPE BETWEEN 2002 AND 2011}

In 2011, cardiopulmonary dirofilariasis remains endemic and spreading out the southern European countries; this disease has spread to countries in Eastern and Center of Europe where its presence and distribution were only reported by sporadic cases or not reported at all (Figure 1).

In Italy, D. immitis is endemic in northern Italy and has now spread all over the country, which shows a current change of distribution of this parasite throughout the Italian territory while canine and feline heartworm infection is more frequently diagnosed in southern regions of Italy (Otranto et al., 2009; Traversa et al., 2010a). While the last studies report the lower prevalences published in the endemic area of northern Italy $(6.12 \%$; Piccinini and Carreri, 2010), autochthonous foci of canine dirofilariasis have been described in central regions such as Tuscany and Umbria, which were considered non-endemic until 1999 (PiergilliFioretti et al., 2003; Mortarino et al., 2008). Nowadays, heartworm disease infection has become endemic in these areas (PiergilliFioretti et al., 2003; Mortarino et al., 2008; Magi et al., 2011). In Umbria (hilly central region), where only imported cases have been previously reported, the prevalence ranges between 5 and 15\% (Piergilli-Fioretti et al., 2002, 2003; Genchi et al., 2005; Mortarino et al., 2008). In Tuscany a prevalence of canine dirofilariasis of 12.5\% was reported (Mortarino et al., 2008; Magi et al., 2011). Furthermore, D. immitis has been detected for the first time in autochthonous dogs living in another previously Dirofilaria free region of central Italy, i.e., Abruzzo, close to Umbria and Lazio regions (Paoletti et al., 2008). In a recent study carried out in 2008 and 2009, in the Abruzzo region of central Italy prevalences of 2.3 and $0.3 \%$ were found in native dogs and cats, respectively (Traversa et al., 2010a). In a recent survey dogs from four different areas of southern Italy were sampled (Apulia and Calabria regions), and prevalences between 0.24 and $2.57 \%$ were found in Apulia region while prevalence of $3.43 \%$ was found in Calabria region (Otranto et al., 2009). In Sardinia, where the prevalence was very low in the past $(<2 \%)$, there has been an increasing pattern of prevalence, rising to $17 \%$ in the central west area of the island (Scala et al., 2004). D. immitis infections in cats has been diagnosed mostly in northern Italy where prevalences between 7 and 27\% have been found, depending on location, in the hyperendemic area of the Po River valley (Kramer and Genchi, 2002; Genchi et al., 2008). In the central area of Italy a prevalence of $23.5 \%$ is reported in cats living in Tuscany (Magi et al., 2002). In Tuscany too, epidemiologic studies observe the presence of adults of $D$. immitis between 6.06 and $7.1 \%$ of the red foxes studied (Magi et al., 2008, 2009). For the first time, has been described the first diagnosis of mature heartworm infection and presence of microfilariae in an exotic felid (Panthera pardus pardus) in north-eastern Italy (Mazzariol et al., 2010). Furthermore, a case of $D$. immitis in a wolf in the south of Italy was reported (Pascucci et al., 2007).

In Spain, a epidemiological study carried out in 2006, reports high prevalences in the Mediterranean coast (18\% in Alicante, $9 \%$ in Murcia) and on the island of Ibiza (39\%; Rodes, 2006), while in Mallorca recently was reported a case of dirofilariasis in a dog which never traveled outside the island (Makowski et al., 2010). Another study shows prevalences of $2 \%$ in Barcelona, $0.85 \%$ in
Tarragona, and $0.3 \%$ on the island of Mallorca (Solano-Gallego et al., 2006). In the center of the Iberian Peninsula high prevalences are reported in Arganda del Rey (8\%), Azuqueca de Henares $(24 \%)$, and Guadalajara (10\%), areas of influence of the Henares, Jarama, and Tajuña rivers (Gómez-Bautista and Ortega-Mora, 2002). In a study carried out in Salamanca between 2008 and 2009 , a prevalence of $29.08 \%$ is observed, similar to that reported 20 years ago (Morchón et al., 2011b). Besides, for the first time significant $D$. immitis prevalences are found in two Northern provinces: La Rioja (12\%) and La Coruña (4.2\%; Simón et al., 2009a; Morchón et al., 2010). On the island of Gran Canaria, the prevalence of canine dirofilariasis has been gradually dropping, from $23.87 \%$ in 2002 (Sosa et al., 2002) to $19.2 \%$ in 2010 (Montoya-Alonso et al., 2011). On the island of Tenerife, the prevalence remains constant ranging from $22.3 \%$ in 2001 to $21 \%$ in 2006 (Morales et al., 2001; Montoya et al., 2006). Regarding feline dirofilariasis, on the island of Gran Canaria two seroepidemiologic studies show an increase of the prevalence from 18.3 to $33 \%$ between 2004 and 2011 (Morchón et al., 2004; Montoya-Alonso et al., 2011). In 2006, the first diagnosis of D. immitis infection in an African lion (Panthera leo) born and living in Alicante is described (Ruiz de Ybáñez et al., 2006). Besides, exists a report of D. immitis infection in a fox from the north-eastern of Spain (Mañas et al., 2005). Finally, a study carried out in Eurasian otter (Lutra lutra), 48 Eurasian otters from different regions of the Iberian Peninsula were examined, finding $D$. immitis prevalence of 2.1\% (Torres et al., 2004).

In Portugal, in 2011 the overall canine prevalence in the north and north center of Portugal is $2.1 \%$ (Balreira et al., 2011), with the higher prevalences found in Aveiro (6.8\%) and Coimbra (8.8\%). In the last 15 years there is not published any study of prevalence in the south of Portugal, although a study carried out on five Eurasian otter (Lutra lutra) from Alentejo, found D. immitis in two of them (Torres et al., 2004). In cats, a study carried out in the north and north-center of Portugal reports a D. immitis seroprevalence of 17.51\% (Vieira et al., 2011).

In France, in 2009, a canine prevalence of $0.22 \%$ was found in an epidemiologic study carried out in most of the national territory; the positive results came from dogs from Corsica and Boches-duRhône, in the south of France; local prevalence in the department Bouches du Rhône is $2.1 \%$ and even higher local prevalence is determined for Corsica (12.5\%; Pantchev et al., 2009). Simultaneously, a study was done over dogs with clinical signs compatible with $D$. immitis infection. In this group, D. immitis is confirmed in the $6.87 \%$ of the dogs. Of these, most of them are from the South of France, where local prevalences are $27.3 \%$ for Corsica and $22.2 \%$ for Boches-du-Rhône, and the only two positive cases from the northern part of the country likely came into France from abroad: one was brought from Martinique and other one from French Guyana (Pantchev et al., 2009). The authors of the study suggested that an expansion of the Southern endemic areas of $D$. immitis into the North has not occurred. They also indicated that dogs in the Southern areas of the country are still at a high risk of heartworm infection.

In Greece, although in 2001 the prevalence found in the Attiki region, in the south of the country, was $0.7 \%$ (Diaku, 2001), other study carried out in 2003, reported D. immitis infections in $13.1 \%$ 
of the studied dogs in the environs of Athens, in the province of Attiki (Jensen et al., 2003). Since then the disease is considered endemic in the south of the country too. Lefkaditis and Koukeri (2005) reported in that dirofilariasis is a common parasitic disease in Thessaloniki and the most recent study shows a D. immitis prevalence of $17.9 \%$ in dogs living on the eastern foothills of $\mathrm{Mt}$ Olympus in Northern Greece (Lefkaditis et al., 2010).

In Turkey the disease is widely spread showing prevalences between 1 and 27\%. In Istanbul the infection affects the 1.52\% of the dogs (Öncel and Vural, 2005), 2\% in the area of Gemlik of Bursa (Civelek et al., 2007), 9.6\% in the province of Kayseri (Yildirim et al., 2007), and $26 \%$ in the province of Hatay. A study carried out by Simsek et al. (2008) reports prevalences of $14.8 \%$ in Ankara, $12.3 \%$ in Sakarya, $10.5 \%$ in Mersin, and 18.3\% in Kocaeli. Finally, in the region of Kirikkale positive cases were also reported (58\% of the infected dogs were microfilaremic and $27.46 \%$ were amicrofilaremic; Yildiz et al., 2008).

In Germany there is an increase in the number of infected dogs reported, most of them imported from endemic areas. Between 2005 and 2006, the prevalence was 1.2\% (5.483 samples included in the study; Hirsch and Pantchev, 2008), between 2008 and 2010 was $1.49 \%$ (8.545 samples included in the study), of which $30 \%$ were microfilaremic, and between 2009 and 2010 the prevalence was $2.6 \%$ (Pantchev et al., 2009, 2011). It is not considered an endemic country since, up to date, all reported cases corresponded to imported animals, most of them coming from Corfu, Sardinia, Bulgaria, Hungary, and Canary Islands.

In United Kingdom isolated cases are still being diagnosed. Recently a dog was diagnosed and not registered as autochthonous so far, since it is not clear if the dog have previously been in endemic areas (Traversa et al., 2010b).

In Rumania the only study found, published by Sofía et al. (2007) reported the presence of Dirofilaria spp. in $23.07 \%$ of the studied dogs, which provides evidence of the current presence of the parasite in the country, which is considered an endemic country.

In Bulgaria between 2001 and 2006, 6.6\% of the studied dogs were infected and, besides, $8.62 \%$ were microfilaremic (Kostadinov, 2007). In this country, canine dirofilariasis is not currently considered a rare disease but an endemic disease. Exceptionally, the presence of $D$. immitis has been reported in foxes $(3 \%)$ and jackals (8.9\%; Kirkova et al., 2007).

In Hungary two studies have been published, reporting two infected dogs; one of them constitutes the first autochthonous diagnosis which is why it is currently considered an endemic country (Farkas, 2003; Jacsó et al., 2009).

In Croatia and Serbia several studies demonstrate the presence of dirofilariasis as an endemic disease in these countries and its constant spreading. In Serbia, between 2006 and 2007 the global prevalence reported was $7.2 \%$ and, specifically, in the regions of Vojvodina and Branicevo was 7.2 and $3.17 \%$ respectively (Zivicnjak et al., 2006; Dimitrijevic et al., 2007; Tasic et al., 2008). In the region of Belgrade, a few years later the prevalence was $22.01 \%$, showing co-infections with $D$. repens in $3.97 \%$ of the dogs. In Kosovo, the global prevalence is $9 \%$ and in the northern areas of the country increases up to $6.57 \%$ reaching $16.1 \%$ in some areas (Lazri et al., 2008). In the Istria Peninsula in Croatia, the canine dirofilariasis reaches prevalences of 16 and $8 \%$ in the southern areas. In the south of Slovakia, between 2007 and 2008, two studies showed $D$. immitis infection in 10 dogs co-infected by $D$. repens (Miterpáková et al., 2010).

In the Czech Republic, Svobodová et al. (2002) detected the first endogenous case of heartworm disease in dogs therefore is currently considered an endemic country. Two years later 89 infected dogs were detected, being one of them imported from an endemic area (Svobodová and Misonova, 2005). Finally, Dobesova et al. (2007) reported a prevalence of $6.7 \%$ with co-infection with $D$. repens in $2.7 \%$ of the dogs, all of them collected near Austria and Slovakia.

In Albania, between 2007 and 2008 prevalence was 3\% in the district of Tirana and 7\% in samples collected between Albania and Kosovo (Lazri et al., 2008; Hamlet et al., 2009).

In Russia, dirofilariasis is currently considered an emerging disease. Lately, numerous cases are appearing in the center and southern areas of the country. In the region of Moscow, canine dirofilariasis has been reported in 33 districts, all of them coinfected by D. repens (Supriaga et al., 2011) and in the region of Rostov (south of Russia), between 2002 and 2009, 6.1\% of the studied dogs presented $D$. immitis, $5 \%$ of them co-infected by $D$. repens and microfilaremic (Kartashev et al., 2011); currently, the region of Rostov is considered an endemic area.

\section{VECTOR TRANSMISSION OF DIROFILARIASIS}

Several studies carried out in endemic areas researched which vector species are transmitting agents of cardiopulmonary dirofilariasis. To that end, vector mosquitoes have been captured through field studies using animal-bait traps; besides, these studies allowed the evaluation of the different mosquito species attracted to the hosts and the evaluation of the effectiveness of the transmission of the parasite (Cancrini and Kramer, 2001). These studies have been carried out in several areas of the globe (Unites States of America, Brazil, Italy, Iran. .. ); animals (dog and cat) and/or humans have been used as bait. Approximately 70 species of culicid mosquitoes mainly from the genera Culex spp., Aedes spp., Anopheles spp., Culiseta spp., and Coquilletidia spp. have been identified, and are considered potential vectors of animal and human dirofilariasis, although only in a few cases its real vectorial capacity could be proven (Cancrini and Kramer, 2001; Cancrini et al., 2006).

Various studies in Europe had reported several species of mosquitoes infected by $D$. immitis larvae such as $C x$. pipiens in Spain (Morchón et al., 2007), Italy (Cancrini et al., 2006), and Turkey (Yildirim et al., 2011); Cx. theileri in Madeira, Portugal (Santa-Ana et al., 2006), and on the Canary Islands, Spain (Morchón et al., 2011a); Ae. vexans in Turkey (Biskin et al., 2010; Yildirim et al., 2011) and Ae. albopictus, Ae. caspius, An. maculipennis, and Cq. richiardii in Italy (Cancrini et al., 1995, 2003, 2006).

In Europe, the activity of these species is limited to the period of time between spring and summer, whereas the behavior of the mosquitoes when search a host to feed follows different patterns depending on the species. Some are active only during the night, such as $C x$. pipiens, Anopheles spp. while others are active predominantly at dawn or during the day (An. maculipennis, Ae. albopictus) and some other species show two peaks of activity: at dusk and at 
dawn, such as Ae. caspius (Mattingly, 1969; Di Sacco et al., 1992; Pollono et al., 1998).

Mosquito development and activity are regulated by climate, primarily temperature and humidity, just as L3 development depends on the ambient temperature. It has been demonstrated experimentally that infectious $\mathrm{L} 3$ development requires 8-10 days at $28-30^{\circ} \mathrm{C}, 11-12$ days at $24^{\circ} \mathrm{C}$, and $16-20$ days at $22^{\circ} \mathrm{C}$. Below $14^{\circ} \mathrm{C}$, development arrests, although it can be restarted when the ambient temperature increases above this threshold (Cancrini and Gabrielli, 2007). Consequently, the climate and its changes determine the transmission and presence of dirofilariasis in temperate regions (Genchi et al., 2005). A good example of the impact of climate on the distribution and prevalence of dirofilariasis is illustrated by the island of Gran Canaria. With only $40 \mathrm{~km}$ of diameter, this hyperendemic island is divided in four different isoclimatic areas depending on altitude, with marked temperature and humidity differences among them. As consequence, the prevalence of $D$. immitis is significantly different between the canine populations of each zone, varying from 12 to $32 \%$ (Montoya-Alonso et al., 2010b).

There is currently a scientific consensus regarding the existence of anthropogenic climate change, which is ascribed to natural processes and human activity altering atmospheric conditions with an increase of the worldwide mean surface temperature by $0.74^{\circ} \mathrm{C}$ (Threnberth, 2005; Semenza and Menne, 2009). Global warming affects host-parasite systems by influencing the amplification and emergence of parasite populations, inducing changes in the development and survival rates of both parasite and vector and altering seasonal transmission dynamics (Brooks and Hoberg, 2007). With respect to dirofilariasis, climate change is lengthening annual periods of mosquito activity, shortening larval developmental stages, and increasing transmission across multiple geographical regions, which means more suitable conditions for its spread toward new areas.

\section{FACTORS CONTRIBUTING TO THE SPREADING OF CANINE CARDIOPULMONARY DIROFILARIASIS}

The analysis of the epidemiologic studies carried out until 2001 and between 2002 and 2011 show a change in the pattern of distribution of the disease, with a spreading toward north and Eastern Europe. The results of these epidemiologic analyses are summarized in the Table 1. Between 2002 and 2011 there are reports of canine dirofilariasis in countries and regions previously considered free of the disease (Sofía et al., 2007; Simón et al., 2009a; Morchón et al., 2010; Kartashev et al., 2011) and there have been reported autochthonous cases of dirofilariasis in countries where previously only imported cases had been reported (Svobodová et al., 2002; Farkas, 2003; Jacsó et al., 2009; Makowski et al., 2010). The cause of this spreading might be multifactorial, and in this review we discuss the different factors affecting the changes of the distribution of cardiopulmonary dirofilariasis in Europe.

There are several factors which exert a big influence on the spreading of the disease (Genchi et al., 2001). In the first place, the presence and movement of microfilaremic reservoirs, as well as the increasing number of dogs traveling for holidays or commerce of dogs from endemic areas being relocated, are key factors for the maintenance of the infection in endemic regions and the spread
Table 1 | Distribution of animal dirofilariasis in Europe until 2011 and between 2002 and 2011.

\begin{tabular}{|c|c|c|c|}
\hline & Until 2001 & $\begin{array}{l}2002- \\
2011\end{array}$ & Vectors \\
\hline Portugal & $\bullet$ & $\bullet$ & Cx. theileri \\
\hline Spain & $\bullet$ & 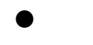 & Cx. pipiens, Cx. theileri \\
\hline Italy & $\bullet$ & ○ & $\begin{array}{l}\text { C. pipiens, Ae. } \\
\text { albopictus, Ae. caspius, } \\
\text { An. maculipennis, Cq. } \\
\text { richiardii }\end{array}$ \\
\hline
\end{tabular}

France

Greece

Turkey

Switzerland

Austria

Germany

United Kingdom

Netherlands

Macedonia

Rumania

Croatia

Serbia

Slovenia

Bulgaria

Albania

Slovakia

Czech Republic

Hungary

Republic of Azerbaijan

Turkmenistan

Russia - region of Rostov

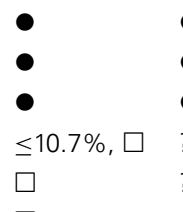

$\square \quad \leq 2.9 \%$ ?
Cx. pipiens, Ae. vexans

?
Endemic area ( ), isolated cases ( $\mathbf{\square})$, imported cases ( $\square$ ) and no data (?)

into new areas. It is important to mention the role as reservoir of other animals, such as the coyote in California (Sacks, 1998) and the fox in Australia (Marks and Bloomfield, 1998); in Europe, the role of foxes or wolves as reservoirs of dirofilariosis could be important factors to consider when studying the factors contributing to the maintenance and spreading of the disease. Another fundamental factor is the presence of mosquitoes able to act as vectors, as well as the existence of adequate climate conditions for its correct development. Furthermore, it is necessary take into account the introduction in a given area of new species of competent mosquitoes; Aedes albopictus represents an example of this, which being native from southeastern of Asia and western Pacific has spread to Europe, Africa, and America in the last decades. This quick spreading has been facilitated by international transport nets of used tires and gardening products, as well as by accidental transport of adults in vehicles from close affected areas (Reiter and Sprenger, 1987; Madon et al., 2002; Flacio et al., 2004; Roiz et al., 2007). Besides, A. albopictus is a highly adaptable species; in temperate areas its activity period is limited to summer, surviving during the winter in egg-stage, a fact not observed in the mosquito colonies from the tropical areas (Hawley et al., 1987; Mitchell, 1995). In general, a region is susceptible to be colonized by stable colonies of $\mathrm{Ae}$. 
albopictus when the average temperature is $0^{\circ} \mathrm{C}$ in winter, $20^{\circ} \mathrm{C}$ in summer and presents at least $50 \mathrm{~cm}$ of annual rainfall (Knudsen et al., 1996). In Europe was found for the first time outside its area of origin in 1979 in Albania (Adhami and Reiter, 1998); later was detected in Italy, where have become a plague (Romi, 2001). Currently it is also present in France, Montenegro, Switzerland, Greece, Spain, Croatia, Bosnia-Herzegovina, Slovenia, Belgium, Netherland, and Germany (Schaffner and Karch, 2000; Pétric et al., 2001; Flacio et al., 2004; Schaffner et al., 2004; Samanidou-Voyadjoglou et al., 2005; Aranda et al., 2006; Kloblucar et al., 2006; Scholte and Schaffner, 2007; Pluskota et al., 2008; Scholte et al., 2010). There is a concern about the marked anthropophilia observed in Ae. albopictus regarding its involvement on the transmission of several diseases to the human population (dirofilariasis amongst them; Cancrini et al., 1995). Its vectorial capacity has been proved in the transmission of Dengue fever and Yellow fever, is a potential vector for several arbovirus (Mitchell, 1995) and its capacity to transmit infective larvae of $D$. immitis has been confirmed in its area of origin, in Italy and some areas of North America (Comiskey and Wesson, 1995; Cancrini et al., 2003; Gratz, 2004). In a recent study of the nutritional habits of the mosquito carried out in the province of Rome, it was observed that in the urban areas Ae. albopictus fed almost exclusively on humans, while in rural areas they show a mixed feeding pattern (human-horse and human-dog; Valerio et al., 2010).

Other potential vector species of heartworm disease is Ae. aegypti. This species was vey abundant in the early twentieth century in Southern Europe and in harbor cities of the Mediterranean Basin, mainly in Syria, Lebanon, Turkey, Greece, former Yugoslavia, Italy, Corsica (France), and Spain. Currently, constitutes a potential vector of the disease in America (Vezzani et al., 2006, 2011b); however, in Europe it has not been proven as a vector of the disease except in experimental infections (Scholte et al., 2010).

The environmental conditions constitute another important factor affecting the distribution of the disease; these play an essential role in the distribution of the dirofilariasis. Because of the climate change, influenced by the global warming, the vector population has more suitable conditions for its development, increasing the geographical distribution of vectors and the number of mosquitoes able to transmit the disease, as well as the suitable temperatures allow to expand the risk season for the transmission of the disease by favoring the development of infectious larvae in the vector (Genchi et al., 2009), as well as the insertion and spreading of vectors from another areas (Hendrickx et al., 2004; Rogers and Randolph, 2006). Other studies have demonstrated the influence of the climate change in the spreading of other vector-borne diseases in Europe (Semenza and Menne, 2009). On the other hand, it is also important to take into consideration the changes in ecology and the habitat, alterations in the system and water storage, the pollution and the development of resistances to insecticides (Harrus and Baneth, 2005). Building construction and human activity in new areas play an important role given that increases the density of potential hosts and develops a suitable environment for the proliferation of certain species of mosquitoes; the development of residential settlements of non-endemic areas and areas of low incidence led to the spread and increased prevalence of heartworms by altering drainage of undeveloped land and by providing water sources in new urban home sites. Besides, urban sprawl has led to the formation of "heat islands," as buildings retain heat during the day and subsequently radiate it during the night, which can potentially create microenvironments that support development of heartworm larvae in mosquito vectors during colder months, thus lengthening the transmission season (Arnfield, 2003). Considering these factors, the most favorable environments for the spreading of the dirofilariasis are characterized by high humidity and temperature, which allow the adequate development and activity of the vector. It has been demonstrated that the irrigated lands for farming present higher prevalences that those areas close to them (Gortázar et al., 1998; Montoya-Alonso et al., 2010a). All the mentioned factors might be determinant for the spreading, as well as the rise of the prevalence in new areas (i.e., south of Greece and Italy) where, due to the unawareness of this disease, not adequate prophylactic measurements were taken. On the other hand, due to the increase of the incidence of canine dirofilariasis, a greater attention by the scientific community toward these areas is being paid, resulting in more accurate and numerous epidemiologic studies.

It is also important to notice that, based on the results of the epidemiological studies carried out until 2001 and between 2002 and 2011, a decrease of the prevalence of canine dirofilariosis in hyperendemic areas has been observed. This is clearly seen in the northern Italy, where the prevalence has decreased from 50 to $80 \%$ to nearby $6 \%$ in the last published study (Piccinini and Carreri, 2010); also, the island of Gran Canaria (Spain) has experienced a decrease of canine dirofilariasis from $67 \%$ in 1994 to $19 \%$ in 2010 (Montoya et al., 1998). This might be caused by the fact that preventive therapy had begun to be administered continuously to the canine population thanks to the education of the pet owner and a better understanding of the disease (Montoya-Alonso et al., 2010a). Similar trends have been observed in other endemic areas outside Europe, where a decrease in canine dirofilariasis prevalences have been described recently (Labarthe and Guerrero, 2005; Vezzani et al., 2011a); the authors conclude that this trend might be due to effective chemoprophylaxis, the abusive use of injectable ivermectin and the extensive use of tetracyclines to control other infections.

\section{CONCLUSION}

Finally, on the basis of results in this review, it is possible to confirm that the prevalence of canine and feline dirofilariasis is increasing and spreading to the north-eastern and center European countries, being reported new cases of canine dirofilariosis in countries previously considered free of the disease, or being diagnosed more often, as well as the first reports of autochthonous cases in countries where previously only imported cases were described. In general, the increased movement of infected dogs across Europe, a greater attention toward the disease, the climate change, the emergence of new species of vectors and changes in ecosystem due to human activity, lifestyle of people, are the possible causes of this increase. In these countries, this should be controlled by periodic heartworm antigen test done in veterinary clinics for detection of $D$. immitis infection and a correct prevention protocol should be carried out in all traveling 
dogs, in the same way that correct protocols of early diagnosis and prevention of heartworm disease has been performed in hyperendemic areas for years, resulting in a decrease of the

\section{REFERENCES}

Adhami, J. R., and Reiter, P. (1998). Intoduction and establishment of Aedes (Stegomya) albopictus Skuse (Diptera, Culicidae) in Albania. J. Am. Mosq. Control Assoc. 14, 340-343.

Anguera-Galiana, M. (1995). La dirofilariosis canina en el Delta del Ebro. Med. Vet. 12, 242-246.

Anguiano, A., Martínez-Cruz, S., and Gutiérrez, P. N. (1985). "Epidemiología de la dirofilariasis canina en la provincia de Córdoba," in $I V$ Congreso Nacional de Parasitología, Tenerife.

Aranda, C., Eritjar, R., and Roiz, D. (2006). First record and establishment of the mosquito Aedes albopictus in Spain. Med. Vet. Entomol. 20, 150-152.

Aranda, C., Panyella, O., Eritja, R., and Castella, J. (1998). Canine filariasis. Importance and transmission in the Baix Llobregat area, Barcelona (Spain). Vet. Parasitol. 77, 267-275.

Araujo, A. M. (1996). Canine and human Dirofilaria immitis infections in Portugal. A review. Parassitologia 38, 366.

Arnfield, A. J. (2003). Two decades of urban climate research: a review of turbulence, exchanges of energy and water, and the urban heat island. Int. J. Climatol. 23, 1-26.

Arnold, P., Deplazes, P., Ruckstuhl, H., and Flückiger, M. (1994). Fallbericht, Dirofilariose beim Hund. Schweiz. Arch. Tierheilk. 136, 265-269.

Arru, E., Nuvole, A., and Mann, P. (1968). La filariosi del cane in Sardegna. Riv. Parasitol. 30, 49-58.

Artamonova, A., Nagorny, S., Strelnikova, G., and Levchenko, L. (1997). "Human and canine dirofilariosis in Rostov region," in Proceedings of the 7th USSR Congress of the Society of Epidemiologists, Microbiologists, Parasitologists, Moscow, 326-327.

Balreira, A. C., Silvestre-Ferreira, A. C., Fontes-Sousa, A. P., Vieira, L., Carretón, E., and Montoya-Alonso, J. A. (2011). "Epidemiological survey of Dirofilaria immitis infection in dogs on the North and North Centre of Portugal - preliminary results," in International Workshop of Dirofilaria, Gran Canaria, 40-41.

Beaufils, J. P., Martin-Granel, J., and Bertrand, F. (1991). Présance de microfilaires de Dirofilaria immitis dans les urines d'un chat occlus. Prat. Med. Chir. Anim. Com. 26, 467-472.
Boros, G., Janisch, M., and Sebestyen, G. (1982). Dirofilaria immitis in dogs. Magy Allatorvosok Lapja 37, 313-316.

Brglez, J., and Senk, L. (1987). Dirofilaria immitis (Leidy, 1856) Railliet et Henry, 1911, in a dog Dirofilaria immitis (Leidy, 1856) Railliet et Henry, 1911, pri psu. Zbornik Biotehniske Fakultete Univerze Edvardo Kardelja v Ljubljani. Veterinarstvo 24, 69-72.

Brooks, D. R., and Hoberg, E. P. (2007). How will global climate change affect parasite-host assemblages? Trends Parasitol. 23, 571-574.

Bucklar, H., Scheu, U., Mossi, R., and Deplazes, P. (1998). Breitet sich in der Sudschweiz die Dirofilariose beim Hund aus? Schweiz. Arch. Tierheilkd. 140, 255-260.

Biskin, Z., Düzlü, O., Yildirim, A., and Inci, A. (2010). The molecular diagnosis of Dirofilaria immitis in vector mosquitoes in Felahiye district of Kayseri. Turkiye Parazitol. Derg. 34: 200-205.

Cancrini, G., Frangipane di Regalbono, A., Ricci, I., Tessarin, C., Gabrielli, S., and Pietrobelli, M. (2003). Aedes albopictus is a natural vector of Dirofilaria immitis in Italy. Vet. Parasitol. 118, 195-202.

Cancrini, G., and Gabrielli, S. (2007). "Vectors of Dirofilaria nematodes, biology, behaviour and host/parasite relationships," in Dirofilaria Immitis and D. repens in Dog and Cat and Human Infections, eds C. Genchi, L. Rinaldi, and G. Cringoli (Zagreb: Rolando Editore), 47-58.

Cancrini, G., and Kramer, L. (2001). "Insect vectors of Dirofilaria spp," in Heartworm Infection in Humans and Animals, eds F. Simón and C. Genchi (Salamanca: Ediciones Universidad de Salamanca), 63-82.

Cancrini, G., Magi, M., Gabrielli, S., Arispici, M., Tolari, F., Dell'Omodarme, M., and Prati, M. C. (2006). Natural vectors of dirofilariasis in rural and urban areas of the Tuscan region, central Italy. J. Med. Entomol. 43, 574-579.

Cancrini, G., Pietrobelli, M., Frangipane di Regalbono, A. F., Tampieri, M. P., and della Torre, A. (1995). Development of Dirofilaria and Setaria nematodes in Aedes albopictus. Parassitologia 37, 141-145.

Castillo, J. A., Lucientes, J., Estévez, C., and Gortazar, C. (1989). "Epidemiología de la dirofilariosis en Zaragoza I. Estudio de la prevalencia

prevalence of the disease in those areas and contributing to the change in the distributions pattern of the canine cardiopulmonary dirofilariasis.

en perro y zorro y su interrelación," in VI Congreso Nacional y I Ibérico de Parasitología, Cáceres.

Civelek, T., Yildirim, A., Ica, A., and Duzlu, O. (2007). "Prevalence of canine heartworm disease in the Gemlik area of Bursa Province, Turkey," in Dirofilaria immitis and D. repens in Dog and Cat and Human Infections, eds C. Genchi, L. Rinaldi, and G. Cringoli (Zagreb: Rolando Editore), 207.

Comiskey, N., and Wesson, D. M. (1995). Dirofilaria (Filarioidea, Onchocercidae) infection in Aedes albopictus (Diptera, Culicidae) collected in Louisiana. J. Med. Entomol. 32, 734-737.

Coskun, S. Z., Tinar, R., Akyol, C. V., Aydin, L., and Demir, S. (1992). Dogal enfekte köpeklerde Dirofilaria immitis mikrofilerlerine ivermektinin etkisi. Uludag Univ. Vet. Fak. Derg. 11, 121-128.

Cringoli, G., Rinaldi, L., Veneziano, V. and Capelli, G. (2001). A prevalence survey and risk analysis of filariosis in dogs from the Mt. Vesuvio area of southern Italy. Vet. Parasitol. 102 243-252.

Deplazes, P., Guscetti, F., Wunderlin, E., Bucklar, H., Skaggs, J., Wolff, K. (1995). Endoparasitenbefall bei Findel-und Verzicht-Hunden in der Sudschweiz. Schweiz. Arch. Tierheilkd. 137, 172-179.

Di Sacco, B., Cancrini, G., and Genchi, C. (1992). Studio del tropismo nei riguardi del cane e del gato da parte dei ditteri potenziali vettori delle filariosi in provincia di Pavia. Parassitologia 34, 11-12.

Diaku, A. (2001). The prevalence of canine dirofilariosis in the region of Attiki. Bull. Hell. Vet. Med. Soc. 52, 152-156.

Dimitrijevic, S. (1999). Dirofilarioza ante portas. Savetovanje Klin. Vet. 1, 58.

Dimitrijevic, S., Tasic, A., Tasic, S., Adamovic, V., Ilic, T., and Miladinovic-Tasic, N. (2007). "Filariosis in dogs in Serbia," in Dirofilaria immitis and D. repens in Dog and Cat and Human Infections, eds C. Genchi, L. Rinaldi, and G. Cringoli (Zagreb: Rolando Editore), 201.

Dobesova, R., Svobodová, Z., and Svobodová, V. (2007). "Dirofilariosis in dogs - the actual situation in the Czech Republic," in Dirofilaria immitis and D. repens in Dog and Cat and Human Infections, eds C. Genchi, L. Rinaldi, and G. Cringoli (Zagreb: Rolando Editore), 198.
Doby, J. M., Couatarmanach, A., and Aznar, C. (1986a). Filarioses canines par Dirofilaria immitis (Leidy, 1856) et D. Repens Raillet et Henry, 1911, dans l'ouest de la France. Bull. Soc. Française Parasitol. 4, 229-233.

Doby, J. M., Guiguen, C., and Lefeuvre, R. (1986b). Présence de Dirofilaria immitis (Leidy, 1856) chez le chien en Bretagne. Bull. Soc. Française Parasitol. 4, 51-54.

Ducos de Lahitte, J. (1990). Epidemiology of filariases in France. Prat. Méd. Chir. Anim. Compagnie 25, 305-310.

Farkas, R. (2003). "Dirofilariosis in Hungary," in Proceedings of the Helminthological Colloquium 2003, eds H. Auer, C. Hörweg, H. Prosl, and H. Sattmann (Vienna: Austrian Society of Tropical Medicine and Parasitology), 13.

Flacio, E., Lüthy, P., Patocchi, N., Guidotti, F., Tonolla, M., and Peduzzi, R. (2004). Primo ritrovamento di Aedes albopictus in Svizzera. Boll. Soc. Ticinese Sci. Nat. 92, 141-142.

Founta, A., Theodoridis, Y., Frydas, S., and Chliounakis, S. (1999). The presence of filarial parasites of dogs in Serrae province. Bull. Hell. Vet. Med. Soc. 50, 315-320.

Furlanello, T., Caldin, M., Vezzoni, A., Venco, L., and Kitagawa, H. (1998). "Patogenesi," in La Filariosi Cardiopulmonare del Cane e del Gatto eds C. Genchi, L. Venco, and A. Vezzoni (Cremona: Editorial Scivac), 31-46.

Genchi, C., Guerrero, J., Di Sacco, B. and Formaggini, L. (1992). "Prevalence of Dirofilaria immitis infection in Italian cats," in Proceedings of the Heartwom Symposium '92, ed. M. D. Soll (Batavia, IL: American Heartworm Society), 97-102.

Genchi, C., Kramer, L. H., and Prieto, G. (2001). "Epidemiology of canine and feline dirofilariasis, a global view", in Heartworm Infection in Humans and Animals, eds F. Simón and C. Genchi (Salamanca: Ediciones Universidad de Salamanca), 121-134.

Genchi, C., Mortarino, M., Rinaldi, L., Cringoli, G., Traldi, G., and Genchi, M. (2011a). Changing climate and changing vector-borne disease distribution: the example of Dirofilaria in Europe. Vet. Parasitol. 176, 295-299.

Genchi, C., Kramer, L. H., and Rivasi, F. (2011b). Dirofilarial infections in Europe. Vector Borne Zoonotic Dis. 11, 1307-1317. 
Genchi, C., Rinaldi, L., Cascone, C., Mortarino, M., and Cringoli, G. (2005). Is heartworm disease really spreading in Europe? Vet. Parasitol. 133, 137-148.

Genchi, C., Rinaldi, L., Mortarino, M., Genchi, M., and Cringoli, G. (2009). Climate and Dirofilaria infection in Europe. Vet. Parasitol. 163, 286-292.

Genchi, C., Solari-Basano, F., Marrone, R. V., and Petruschke, G. (1998). "Canine and feline heartworm infection with special emphasis on Italy," in Proceedings of the Heartworm Symposium 98, eds M. D. Soll and D. H. Knigh (Batavia, IL: American Heartworm Society), 75-82.

Genchi, C., Venco, L., Ferrari, N., Mortarino, M., and Genchi, M. (2008). Feline heartworm (Dirofilaria immitis) infection, a statistical elaboration of the duration of the infection and life expectancy in asymptomatic cats. Vet. Parasitol. 158, 177-182.

Genchi, C., Venco, L., Magnino, S., Di Sacco, B., Perera, L., Bandi, C., Pignatelli, P., Formaggini, L., and Mazzucchelli, M. (1993). Aggiornamento epidemiologico sulla filariosi del cane e del gatto. Veterinaria 7 , 5-14.

Georgieva, D., Kirkova, Z., and Ivanov, A. (2001). A study on the incidence and diagnostic of dirofilariosis (heartworm disease) in carnivores. Bulg. J. Vet. Med. 4, 231-236.

Giannetto, S., Pampiglione, S., Santoro, V., and Virga, A. (1997). Research of canine filariasis in Trapani province (western Sicily). Morphology on SEM of male Dirofilaria repens. Parassitologia 39, 403-405.

Gómez-Bautista, M., and Ortega-Mora, L. M. (2002). ¿Es la dirofilariosis una enfermedad frecuente en España? Argos 39, 50.

Gortázar, C., Castillo, J. A., Lucientes, J., Blanco, J. C., Arriolabengoa, A., and Calvete, C. (1994). Factors affecting Dirofilaria immitis prevalence in red foxes in north-eastern Spain. J. Wildl. Dis. 30, 545-547.

Gortázar, C., Villafuerte, R., Lucientes, J., and Fernández-de-Luco, D. (1998). Habitat related differences in helminth parasites of red foxes in the Ebro valley. Vet. Parasitol. 80, 75-81.

Gradoni, L., Pozio, E., and Maroli, M. (1980). Filariasis in foxes in the Province of Grosseto. Ann. Ist. Super. Sanita. 16, 251-256.

Gratz, N. G. (2004). Critical review of the vector status of Aedes albopictus. Med. Vet. Entomol. 18, 215-227.

Guerrero, J., Ducos de la Hitte, J., Genchi, C., Rojo, F., Gómez-Bautista,
M., and Carvalho Valera, M. (1992). "Update on the distribution of Dirofilaria immitis in dogs from southern Europe and Latin America," in Proceedings of the Heartworm Symposium '92, ed. M. D. Soil (Batavia, IL: American Heartworm Society), 31-37.

Guerrero, J., Rodenas, A., Gutierrez Galindo, J., and Florit, F. (1995) "The extension of the prevalence of Dirofilaria immitis in Cataluña, Spain," in Proceedings of the Heartworm Symposium '95, eds M. D. Soll, and D. H. Knigh (Batavia, IL: American Heartworm Society), 73-77.

Guerrero, J., Rojo, F., and Ródenas, A. (1989). Estudio de la incidencia de la enfermedad del gusano del corazón en la población canina española. Med.Vet. 6, 217-220.

Güralp, N. (1981). Helmintoloji. Ankara: Üniversitesi Veteriner Fakültesi Yayin, Üniversitesi Basimevi, 505-512.

Gutiérrez, J., Guerrero, J., Ródenas, A. Castella, J., Muñoz, E., Ferrer, D., and Florit, F. (1995). Evolución de Dirofilaria immitis en Cataluña. Med. Vet. $12,10$.

Hamlet, D., Silaghi, C., Knaus, M., Visser, M., Kusi, I., Rapti, D., Rehbein, S., and Pfister, K. (2009). Detection of Babesia canis subspecies and other arthropod-borne diseases in dogs from Tirana, Albania. Wien. Klin. Wochenschr. 121, 42-45.

Harrus, S., and Baneth, G. (2005). Drivers for the emergence and reemergence of vector-borne protozoal and bacterial diseases. Int. J. Parasitol. 35, 1309-1318.

Hawley, W. A., Reiter, P., Copeland, R. S., Pumpuni, C. B., and Craig, G. B. Jr. (1987). Aedes albopictus in North America, probable introduction in used tyres from northern Asia. Science 236, 1114-1116.

Hendrickx, G., Biesemans, J., and de Deken, R. (2004). "The use of GIS in veterinary parasitology," in GIS and Spatial Analysis in Veterinary Science, ed. P. Durr and A. Gatrell (Wallinford: CABI Publishing), 145-176.

Hinaidy, H. K., Bacowsky, M., and Hinterdorfer, F. (1987). Introduction of Dirofilaria immitis and Dipetalonema reconditum in dogs into Austria. J. Vet. Med. B 34, 326-332.

Hirsch, M., and Pantchev, N. (2008). Vorkommenshäufigkeit der Reisekrankheiten Leishmaniose, Ehrlichiose, Babesiose und Dirofilariose bei in Deutschland lebenden Hunden. Kleintierpraxis 3, 154-165.
Jacsó, O., Mándoki, M., Majoros, G., Pétsch, M., Mortarino, M., Genchi, C., and Fok, E. (2009). First autochthonous Dirofilaria immitis (Leidy, 1856) infection in a dog in Hungary. Helminthologia 46, 159-161.

Jensen, J., Muller, E., and Daugschies, A. (2003). Arthropod-borne diseases in Greece and their relevance for pet tourism. Prakt. Tierarzt 84, 430.

Ježic, J., and Simic, C. (1929). Prilog poznavanju parazitarne invazije pasa u varoši Skoplju. Jugoslov. Vet. Glasnik. 9, 383-384.

Kartashev, V., Batashova, I., Kartashov, S., Ermakov, A., Mironova, A. Kuleshova, Y., Ilyasov, B., Kolodiy, I., Klyuchnikov, A., Ryabikina, E., Babicheva, M., Levchenko, Y., Pavlova, R., Pantchev, N., Morchón, R., and Simón, F. (2011). Canine and human dirofilariosis in the Rostov region (southern Russia). Vet. Med. Int. 685713, 5 .

Kirkova, Z., Ivanov, A., and Georgieva, D. (2007). "Dirofilariosis in digs and wild carnivores in Bulgaria," in Dirofilaria immitis and D. repens in Dog and Cat and Human Infections, eds C. Genchi, L. Rinaldi, and G. Cringoli (Zagreb: Rolando Editore), 204.

Kloblucar, A., Mérdic, E., Benic, N. Blaklaic, Z., and Krcmar, S. (2006) First record of Aedes albopictus in Croatia. J. Am. Mosq. Control Assoc. 22, 147-148.

Knudsen, A. B., Romi, R., and Majori, G. (1996). Ocurrence and spread in Italy of Aedes albopictus, with implications for its introduction into other parts of Europe. J. Am. Mosquito Control Assoc. 12, 177-183.

Kostadinov, M. (2007). "Dirofilariosis among dogs in a small animal practice in the Plovdiv region, Bulgaria," in Dirofilaria immitis and D. repens in Dog and Cat and Human Infections, eds C. Genchi, L. Rinaldi, and G. Cringoli (Zagreb: Rolando Editore), 205.

Kramer, L., and Genchi, C. (2002). Feline heartworm infection, serological survey of asymptomatic cats living in northern Italy. Vet. Parasitol. 104, 43-50.

Labarthe, N., and Guerrero, J. (2005). Epidemiology of heartworm: what is happening in South America and Mexico? Vet. Parasitol. 133, 149-156.

Lazri, T., Duscher, G., Edelhofer, R. Bytyci, B., Gjino, P., and Joachim, A. (2008). Arthropod-borne parasites of dogs, especially Leishmania, in the Kosovo and Albania. Wien. Klin. Wochenschr. 120, 54-58.
Lefkaditis, A. M., and Koukeri, E. S. (2005). The clinical signs and protocol of treatment of 25 infected dogs with Dirofilaria immitis. Bull. Univ. Agric. Sci. Vet. Med. 62, 466-468.

Lefkaditis, M., Koukeri, S., and Cozma, V. (2010). An endemic area of Dirofilaria immitis seropositive dogs at the eastern foothills of Mt Olympus, Northern Greece. Helminthologia 47, 3-7.

Madon, M. B., Mulla, M. S., Shaw, M. W., Kluh, S., and Hazelrigg, J. E. (2002). Introduction of Aedes albopictus (Skuse) in southern California and potential for its establishment. J. Vector Ecol. 27, 149-154.

Magi, M., Calderini, P., Gabrielli, S., Dell'Omodarme, M., Macchioni, F., Prati, M. C., and Cancrini, G. (2008). Vulpes vulpes, a possible wild reservoir for zoonotic filariae. Vector Borne Zoonotic Dis. 8, 249-252.

Magi, M., Guardone, L., Prati, M. C., Tozzini, G., Torracca, B., Monni, G., and Macchioni, F. (2011). Canine filarial infections in Tuscany, central Italy. J. Helminthol. 4, 1-4.

Magi, M., Macchioni, F., Dell'Omodarme, M., Prati, M. C., Calderini, P., Gabrielli, S. Iori, A., and Cancrini, G. (2009). Endoparasites of Red Fox (Vulpes vulpes) in Central Italy. J. Wildl. Dis. 45, 881-885.

Magi, M., Marroncini, A., and Sassetti, M. (1989). Distribution of canine filariasis in Tuscany. Sel. Vet. 30, 1185-1187.

Magi, M., Prati, M. C., Sebastiani, B., Bandecchi, P., and Guberti, V. (2002). Seroprevalence of feline heartworm disease in Tuscany. Vet. Rec. 150, 415-416.

Makowski, M., Fernández, J. J., Sancha, A., Pink, A., and Zamora, F. (2010). Dirofilaria immitis, ¿ha llegado a Mallorca? Argos 122, 24-26.

Mañas, S., Ferrer, D., Castellà J, and Maria López-Martín J. (2005). Cardiopulmonary helminth parasites of red foxes (Vulpes vulpes) in Catalonia, northeastern Spain. Vet. J. 169, 118-120.

Marconcini, A., Magi, M., Macchioni, G., and Sassetti, M. (1996). Filariosis in foxes in Italy. Vet. Res. Commun. 20, 316-319.

Marks, C. A., and Bloomfield, T. E. (1998). Canine heartworm (Dirofilaria immitis) detected in red foxes (Vulpes vulpes) in urban Melbourne. Vet. Parasitol. 78, 147-154.

Mattingly, P. F. (1969). The Biology of Mosquito-Borne Disease. London: Carthy and Sutcliffe. 
Mazzariol, S., Cassini, R., Voltan, L., Aresu, L., and Frangipane di Regalbono, A. (2010). Heartworm (Dirofilaria immitis) infection in a leopard (Panthera pardus pardus) housed in a zoological park in north-eastern Italy. Parasitol. Vect. 3, 25.

McCall, J. V., Genchi, C., Kramer, L. H., Guerrero, J., and Venco, L. (2008). Heartworm disease in animals and humans. Adv. Parasitol. 66, 193-285.

Meyer, H. P., Wolvekamp, P., van Maasen, C., and Stokhof, A. A. (1994). Seven cases of heartworm disease (Dirofilariosis) in dogs in the Netherlands. Vet. Q. 16, 169-174.

Mitchell, C. J. (1995). Geographic spread of Aedes albopictus and potential for involvment in arbovirus cycles in the mediterranean basin. $J$. Vector Ecol. 20, 44-58.

Miterpáková, M., Antolová, D., Hurníková, Z., Dubinský, P., Pavlacka, A., and Németh, J. (2010). Dirofilaria infections in working dogs in Slovakia. J. Helminthol. 84, 173-176.

Montoya, J. A., Morales, M., Ferrer, O., Molina, J. M., and Corbera, J. A. (1998). The prevalence of Dirofilaria immitis in Gran Canaria, Canary Islands, Spain (1994-1996). Vet. Parasitol. 75, 221-226.

Montoya, J. A., Morales, M., Juste, M. C., Bañares, A., Simón, F., and Genchi, C. (2006). Seroprevalence of canine heartworm disease (Dirofilaria immitis) in Tenerife island, an epidemiological update. Parasitol. Res. 100, 103-105.

Montoya-Alonso, J. A., Carretón, E., Corbera, J. A., Juste, M. C., Mellado, I., Morchón, R., and Simón, F. (2011). Current prevalence of Dirofilaria immitis in dogs, cats and humans from the island of Gran Canaria, Spain. Vet. Parasitol. 176, 291-294.

Montoya-Alonso, J. A., Carretón, E., Juste, M. C., Mellado, I., Morchón, R., and Simón, F. (2010a). Epidemiological survey of canine heartworm disease on the island of Gran Canaria (Canary Islands - Spain) between 2000 and 2008. Vet. Parasitol. 173, 165-168.

Montoya-Alonso, J. A., Mellado, I., Carretón, E., Cabrera-Pedrero, E. D., Morchón, R., and Simón, F. (2010b). Canine dirofilariosis caused by Dirofilaria immitis is a risk factor for the human population on the island of Gran Canaria, Canary Islands, Spain. Parasitol. Res. 107, 1265-1269.

Morales, M., Bañares, A., and Montoya, J. A. (2001). "Prevalencia de la parasitación en perros por Dirofilaria immitis en la isla de Tenerife," in 36
Congreso Nacional de la Asociación de Veterinarios Españoles Especialistas en Pequeños Animales, Barcelona.

Morchón, R., Bargues, M. D., Latorre, J. M., Melero-Alcíbar, R., Pou-Barreto, C., Mas-Coma, S., and Simón, F. (2007). Haplotype H1 of Culex pipiens implicated as a natural vector of Dirofilaria immitis in an endemic area of Western Spain. Vector Borne Zoonot. Dis. 7, 653-658.

Morchón, R., Bargues, M. D., Latorre, J. M., Pou-Barreto, C., MeleroAlcíbar, R., Moreno, M., Valladares, B., Molina, R., Montoya-Alonso, J. A., Mas-Coma, S., and Simón, F. (2011a). Molecular characterization of Culex theileri from Canary Islands, Spain, a potential vector of Dirofilaria immitis. J. Clin. Exp. Pathol. S3:001. doi: 10.4172/21610681

Morchón, R., Mellado, I., GonzálezMiguel, J., Hernández, M. V., Hernández, L., and Simón, F. (2011b). Prevalencia de la dirofilariosis cardiopulmonar canina. Argos 126, 30.

Morchón, R., Ferreira, A. C., MartínPacho, J. R., Montoya-Alonso, J. A., Mortarino, M., Genchi, C., and Simón, F. (2004). Specific IgG antibody response against antigens of Dirofilaria immitis and its Wolbachia endosymbiont bacterium in cats with natural and experimental infections. Vet. Parasitol. 125, 313-321.

Morchón, R., Moya, I., GonzálezMiguel, J., Montoya, M. N., and Simón, F. (2010). Zoonotic Dirofilaria immitis infections in a province of Northern Spain. Epidemiol. Infect. 138, 380-383.

Mortarino, M., Musella, V., Costa, V., Genchi, C., Cringoli, G., and Rinaldi, L. (2008). GIS modeling for canine dirofilariosis risk assessment in central Italy. Geospat. Health 2, 253-261.

MSD-AGVET. (1991). Encuesta para ampliación del conocimiento de la prevalencia de la dirofilariosis canina en España. Informes MSD-AGVET España.

Öge, H., Doganay, A., Öge, S., and Yildirim, A. (2003). Prevalence and distribution of Dirofilaria immitis in domestic dogs from Ankara and vicinity in Turkey. Dtsch. Tierarztl. Wochenschr. 110, 69-72.

Olteanu, G. (1996). Dirofilariosis in man and animals in Romania. Parassitologia 38, 360.

Öncel, T., and Vural, G. (2005). Seroprevalence of Dirofilaria immitis in stray dogs in Istanbul and Izmir. Turk. J. Vet. Anim. Sci. 29, 785-789.

Ortega-Mora, L. M., Ferré, I., Gómez, M., and Rojo-Vázquez, F. A. (1988).
Prevalencia de la infestación por filarias en galgos en la zona centro de España. Med. Vet. 5, 433-442.

Ortega-Mora, L. M., Gómez-Bautista, M., Rojo-Vázquez, F., Rodenas, A. and Guerrero, J. A. (1991). Survey of the prevalence of canine filariasis in Spain. Prev. Vet. Med. 11, 63-68.

Otranto, D., Capelli, G., and Genchi, C. (2009). Changing distribution patterns of canine vector borne diseases in Italy, leishmaniosis vs. dirofilariosis. Parasit. Vectors 2(Suppl. 1), S2.

Pampiglione, S., Poglayen, G., and Capelli, G. (1986). Distribuzione geografica delle filariosi canine. Parassitologia 28, 297-300.

Pantchev, N., Etzold, M., Daugschies, A. and Dyachenko, V. (2011). Diagnosis of imported canine filarial infections in Germany (2008) - (2010) Parasitol. Res. 109, 61-76.

Pantchev, N., Norden, N., Lorentzen, L., Rossi, M., Rossi, U., Brand, B. and Dyachenko, V. (2009). Current surveys on the prevalence and distribution of Dirofilaria spp. in dogs in Germany. Parasitol. Res. 105, 63-74.

Paoletti, B., Traversa, D., Guglielmini, C., Iorio, R., Bazzocchi, C., Pampurini, F., and Boari, A. (2008). "Autochthonous canine dirofilariosis in Abruzzo region of central Italy," in Proceedings of the Congress of the Italian Society of Parasitology, Pisa, Vol. 50, 18-21.

Papazahariadou, M. G., Koutinas, A. F., Rallis, T. S., and Haralabidis, S. T. (1994). Prevalence of microfilaemia in episodic weakness and clinically normal dogs belonging to hunting breeds. J. Helminthol. 68, 243-245.

Pascucci, I., Fico, R., D’Angelo, A. R. Serini, S., and Cammà, C. (2007). First notification in Italy of cardiopulmonary filariosis (heartworm disease) in a wolf (Canis lupus). Vet. Ital. 43, 843-850.

Pérez, R., Goméz, M., and Encinas, A. (1989). Canine filariasis in Salamanca (northwest Spain). Ann. Trop. Med. Parasitol. 83, 143-150.

Pétric, D., Pajovic, I., Ignjatovic-Cupina, A., and Zgomba, M. (2001). "Aedes albopictus (Skuse 1895) a new mosquito species (Diptera, Culicidae) in the entomofauna of Yugoslavia (in Serbian)," in Symposia of Serbian Entomologists (2001) (Goc: Entomological Society of Serbia), 29.

Petruschke, G., Rossi, L., Genchi, C. and Pollono, F. (2001). Canine dirofilariasis in the canton of Ticino and in the neighboring areas of northern Italy. Schweiz. Arch. Tierheilkd. 143, 141-147.

Piccinini, G., and Carreri, L. (2010). "An Epidemiologic Assessment of
Canine Heartworm in Northern Italy," in Proceedings of the 13th Trienial State of the Heartworm Symposium, Memphis, 41-42.

Piergilli-Fioretti, D., Diaferia, M., Grelloni, V., and Maresca, C. (2003). Canine filariosis in Umbria, an update of the occurrence one year after the first observation of autochthonous foci. Parassitologia 45, 79-83.

Piergilli-Fioretti, D., Moretti, A., Boni, P., Calducci, M., and D'Andrea, M. (2002). Prima segnalazione di foci autoctoni di dirofilariosi canina in Umbria. Parassitologia 44, 44.

Pietrobelli, M., Soldano, F., Regalbono, A. F., and di Bandiera, C. (1998) Canine heartworm disease in FriuliVenezia Giulia (north-eastern Italy). Obiettivi Doc. Vet. 19, 63-68.

Pluskota, B., Storch, V., Braunbeck, T., Beck, M., and Becker, N. (2008). First record of Stegomyia albopicta (Skuse) (Diptera: Culicidae) in Germany. Eur. Mosq. Bull. 26, 1-5.

Poglayen, G., Martini, M., Bomben, L., and Roda, R. (1996). An update of the occurrence of canine heartworm disease in northern Italy. Vet. Res. Commun. 20, 303-307.

Polizopoulou, Z. S., Koutinas, A. F., Saridomichelakis, M. N., Patsikas, M. N., Leontidis, L. S., Roubies, N. A., and Desiris, A. K. (2000). Clinical and laboratory observations in 91 dogs infected with Dirofilaria immitis in northern Greece. Vet. Rec. 146, 466-469.

Pollono, F., Cancrini, G., and Rossi, L. (1998). Indage sui culicidi attratti da esca canina in Piemonte. Parassitologia 40, 439-445.

Rapti, D., and Rehbein, S. (2010). Seroprevalence of canine heartworm (Dirofilaria immitis) infection in Albania. Parasitol. Res. 107, 481-485.

Reiter, P., and Sprenger, D. (1987). The used tire trade, a mechanism for the worldwide dispersal of container breeding mosquitoes. J. Am. Mosq. Control Assoc. 3, 494-501.

Rodes, D. (2006). Últimos datos epidemiológicos sobre filariosis canina. Argos 79, 52.

Rogers, D. J., and Randolph, S. E. (2006). Climate change and vector-borne diseases. Adv. Parasitol. 62, 345-381.

Roiz, D., Eritja, R., Escosa, R., Lucientes, J., Marqués, E., Melero-Alcíbar, R., Ruiz, S., and Molina, R. (2007). A survey of mosquitoes breeding in used tires in Spain for the detection of imported potential vector species. J. Vector Ecol. 32. 10-15.

Rojo-Vázquez, F. A., Valcárcel, F., Guerrero, J., and Gómez, M. (1990). Prevalencia de la dirofilariosis 
canina en cuatro áreas geográficas de España. Med. Vet. 7, 297-305.

Romi, R. (2001). Aedes albopictus in Italia, un problema sanitario sottovaluato. Ann. Ist. Super. Sanita 37, 241-247.

Rossi, L., Pollono, F., Meneguz, P. G., Gribaudo, L., and Balbo, T. (1996). An epidemiological study of canine filarioses in north-west Italy, what is changed in 25 years? Vet. Res. Commun. 20, 308-315.

Ruiz de Ybáñez, M. R., MartínezCarrasco, C., Martínez, J. J., Ortiz, J. M., Attout, T., and Bain, O. (2006). Dirofilaria immitis in an African lion (Panthera leo). Vet. Rec. 158, 240-242.

Sacks, B. N. (1998). Increasing prevalence of canine heartworm infection in coyotes from California. J. Wildl. Dis. 34, 386-389.

Samanidou-Voyadjoglou, A., Patsoula, E., Spanakos, G., and Vakalis, N. C. (2005). Confirmation of Aedes albopictus (Skuse) (Diptera, Culicidae) in Greece. Eur. Mosq. Bull. 19, $10-12$.

Santa-Ana, M., Khadem, M., and Capela, R. (2006). Natural infection of Culex theileri (Diptera, Culicidae) with Dirofilaria immitis (Nematoda, Filarioidea) on Madeira Island, Portugal. J. Med. Enmintol. 43, 104-106.

Scala, A., Atzori, F., Varcasia, A., Grippa, G., and Genchi, C. (2004). Canine filariosis in Sardinia, epidemiological updating (1998-2004). Atti SISVET 58, 120-122.

Schaffner, F., and Karch, S. (2000). Premiere observation d'Aedes albopictus (Skuse, 1894) en France métropolitaine. Sci. Vie 323, 373-375.

Schaffner, F., Van Bortel, W., and Coosemans, M. (2004). First record of Aedes (Stegomyia) albopictus in Belgium. J. Am. Mosq. Control Assoc. 20, 201-203.

Scholte, E., Den Hartog, W., Dik, M., Schoelitsz, B., Brooks, M., Schaffner, F., Foussadier, R., Braks, M., and Beeuwkes, J. (2010). Introduction and control of three invasive mosquito species in the Netherlands, July-October 2010. Euro Surveill. 11, 15.

Scholte, E., and Schaffner, F. (2007). "Waiting for the tiger: establishment and spread of the Aedes albopictus Mosquito in Europe," in Emerging Pests and Vector-Borne Diseases in Europe, eds W. Takken and B. Knols (Wageningen: Wageningen Academic Publishers), 241-260.

Segovia, J. M., Torres, J., Miquel, J., Llaneza, L., and Feliu, C. (2001). Helminths in the wolf, Canis lupus, from north-western Spain. J. Helminthol. 75, 183-192.
Semenza, J. C., and Menne, B. (2009). Climate change and infectious diseases in Europe. Lancet 9, 365-375.

Simón, F., López-Belmonte, J., MarcosAtxutegi, C., Morchón, R., and Martín-Pacho, J. R. (2005). What is happening outside North America regarding human dirofilariasis? Vet. Parasitol. 133, 181-189.

Simón, F., Morchón, R., and González, J. (2009a). Dirofilariosis canina en La Coruña. Argos 106, 10-12.

Simón, F., Morchón, R., GonzálezMiguel, J., and Marcos-Atxutegi, C., and Siles-Lucas, M. (2009b). What is new about animal and human dirofilariosis? Trends Parasitol. 25, 404-499.

Simsek, S., Utuk, A. E., Koroglu, E., and Rishniw, M. (2008). Serological and molecular studies on Dirofilaria immitis in dogs from Turkey. $J$ Helminthol. 82, 181-186.

Sofía, C., Bacescu, B., Coman, T., Parvu, G. H., Dinu, C., Petrut, T., Bercaru, N., and Amfim, A. (2007). "Dirofilariosis in digs and wild carnivores in Romania," in Dirofilaria immitis and D. repens in Dog and Cat and Human Infections, eds C. Genchi, L. Rinaldi, and G. Cringoli (Zagreb: Rolando Editore), 203.

Solano-Gallego, L., Llull, J., Osso, M., Hegarty, B., and Breitschwerdt, E. (2006). A serological study of exposure to arthropod-borne pathogens in dogs from northeastern Spain. Vet. Res. 37, 231-244.

Sosa, N., Montoya, J. A., and Juste, M. C. (2002). "Situación epidemiológica actual de la dirofilariosis canina en la isla de Gran Canaria (Comunicación)," in I Congreso Universitario de Ciencias Veterinarias y Afines, Madrid.

Stenzenberger, R., and Gothe, R. (1999). Arthropod borne parasitic infections and tick infestations of dogs in Tenerife, Spain. Tierarztl. Prax. 27, 47-52.

Stokhof, A. A., and Wolvekamp, W. T. (1978). Heartworm infected dogs in the Netherlands. Tijdschr. Diergeneeskd. 103, 1121-1129.

Supriaga, V. G., Darchenkova, N. N., Bronshtein, A. M., Lebedeva, M. N., Iastreb, V. B., Ivanova, T. N., Guzeeva, M. V., Timoshenko, N. I., Rakova, V. M., and Zhukova, L. A. (2011). Dirofilariasis in the Moscow Region, a low disease transmission risk area. Med. Parasitol. 1, 3-7.

Svobodová, V., and Misonova, P. (2005). The potential risk of Dirofilaria immitis becoming established in the Czech Republic by imported dogs. Vet. Parasitol. 128, 137-140.

Svobodová, Z., Svobodová, V., Genchi, C., and Forejtek, P. (2002). The first report of authochthonous dirofilariosis in dogs in the Czech Republic. Helminthologia 43, 242-245.

Tasic, A., Rossi, L., Tasic, S., MiladinovicTasic, N., Ilic, T., and Dimitrijevic, S (2008). Survey of canine dirofilariosis in Vojvodina, Serbia. Parasitol. Res. 103, 1297-1302.

Threnberth, K. (2005). Climate. Uncertainty in hurricanes and global warming. Science 308, 1753-1754.

Torres, J., Feliu, C., Fernández-Morán, J., Ruíz-Olmo, J., Rosoux, R., Santos-Reis, M., Miquel, J., and Fons, R. (2004). Helminth parasites of the Eurasian otter Lutra lutra in southwest Europe. J. Helminthol. 78, 353-359.

Traversa, D., Aste, G., Milillo, P., Capelli, G., Pampurini, F., Tunesi, C., Santori, D., Paletti, B., and Boari, A. (2010a). Autochthonous foci of canine and feline infections by Dirofilaria immitis and Dirofilaria repens in central Italy. Vet. Parasitol. 169, 128-132.

Traversa, D., Di Cesare, A., and Conboy, G. (2010b). Canine and feline cardiopulmonary parasitic nematodes in Europe, emerging and underestimated. Parasit. Vectors 3, 62.

Valerio, L., Marini, F., Bongiorno, G., Facchinelli, L., Zombi, M., Caputo, B., Maroli, M., and della Torre, A. (2010). Host-feeding patterns of Aedes albopictus (Diptera: Culicidae) in urban and rura contexts within Rome province, Italy. Vector Borne Zoonotic Dis. 10, 291-294.

Valladares, B., Gijón, H., and LópezRomán, R. (1987). Dirofilaria immitis en la isla de Tenerife. Algunos aspectos de su fisiopatología. Rev. Iber. Parasitol. 47, 377-380.

Vezzani, D., Carbajo, A. E., Fontanarrosa, M. F., Scodellaro, C. F., Basabe, J., Cangiano, G., and Eiras, D. F. (2011a). Epidemiology of canine heartworm in its southern distribution limit in South America: risk factors, inter-annual trend and spatial patterns. Vet. Parasitol. 176, 240-249.

Vezzani, D., Mesplet, M., Eiras, D. F., Fontanarrosa, M. F., and Schnittger, L. (2011b). PCR detection of Dirofilaria immitis in Aedes aegypti and Culex pipiens from urban temperate Argentina. Parasitol. Res. 108, 985-989.

Vezzani, D., Eiras, D. F., and Wisnivesky, C. (2006). Dirofilariasis in Argentina: historical review and first report of Dirofilaria immitis in a natural mosquito population. Vet. Parasitol. 136, 259-273.

Vieira, L., Morchón, R., Fontes-Sousa, A. P., Silvestre-Ferreira, A. C.
Carretón, E., Mellado, I., Simón, F., and Montoya-Alonso, J. A. (2011). "Current seroprevalence of Dirofilaria immitis in cats from the North and North Centre of Portugal," in International Workshop of Dirofilaria, Gran Canaria, 38-39.

Wohlsein, P., Vilafranca, M., and Brandes, B. (1996). Leishmaiose und Filariose bei einem Hund. Kleintierpraxis 41, 367-374.

Yildirim, A., Ica, A., Atalay, O., Duzlu, O., and Inci, A. (2007). Prevalence and epidemiological aspects of Dirofilaria immitis in dogs from Kayseri province, Turkey. Res. Vet. Sci. 82, 358-363.

Yildirim, A., Inci, A., Duzlu, O., Biskin, Z., Ica, A., and Sahin, I. (2011). Aedes vexans and Culex pipiens as the potential vectors of Dirofilaria immitis in Central Turkey. Vet. Parasitol. 178, 143-147.

Yildiz, K., Duru, S. Y., Yagci, B. B., Öcal, N., and Gazyagci, A. N. (2008). The Prevalence of Dirofilaria immitis in Dogs in Kirikkale. Tük. Parazitol. Derg. 32, 225-228.

Zahller, M., Glaser, B., and Gothe, R. (1997). Eingeschleppte Parasiten bei Hunden, Dirofilaria repens un Dipetalonema reconditum. Tierärztl. Prax. 25, 388-392.

Zivicnjak, T., Martinkovic, F., and Beck, R. (2006). "Dirofilariosis in Croatia, spread and public health impact," in 5th Croatian Congress on Infective Diseases, Zadar.

Conflict of Interest Statement: The authors declare that the research was conducted in the absence of any commercial or financial relationships that could be construed as a potential conflict of interest.

Received: 31 January 2012; accepted: 22 May 2012; published online: 12 June 2012.

Citation: Morchón $R$, Carretón $E$ González-Miguel $J$ and MelladoHernández I (2012) Heartworm disease (Dirofilaria immitis) and their vectors in Europe - new distribution trends. Front. Physio. 3:196. doi: 10.3389/fphys.2012.00196

This article was submitted to Frontiers in Systems Biology, a specialty of Frontiers in Physiology.

Copyright (c) 2012 Morchón, Carretón, González-Miguel and MelladoHernández. This is an open-access article distributed under the terms of the Creative Commons Attribution Non Commercial License, which permits noncommercial use, distribution, and reproduction in other forums, provided the original authors and source are credited. 